\title{
The Case for Specific Performance
}

\section{Alan Schwartz ${ }^{\dagger}$}

The purpose of contract remedies is to place a disappointed promisee in as good a position as he would have enjoyed had his promisor performed. ${ }^{1}$ Contract law has two methods of achieving this "compensation goal": requiring the breaching party to pay damages, either to enable the promisee to purchase a substitute performance, or to replace the net gains that the promised performance would have generated; or requiring the breaching party to render the promised performance. Although the damages remedy is always available to a disappointed promisee under current law, the remedy of specific performance is available only at the discretion of the court. Moreover, courts seldom enforce contract clauses that explicitly provide for specific performance in the event of breach.

This Article argues that the remedy of specific performance should be as routinely available as the damages remedy. Part I reviews the current doctrine governing specific performance. Part II argues that the damage remedy is undercompensatory more often than is generally supposed and establishes that promisees have economic incentives not to elect specific performance unless the damage remedy is likely not to provide adequate compensation. Thus, expanding the availability of specific performance would not give promisees an incentive to exploit breaching promisors. Part III goes on to show that making specific performance generally available is unlikely to result in the efficiency losses predicted by other commentators. ${ }^{2}$ Part IV argues that expand-

$\dagger$ Professor of Law, University of Southern California Law Center. This Article benefited greatly from comments received at faculty workshops held at U.S.C. and Hebrew University, Jerusalem, and at a graduate economics seminar at the California Institute of Technology. David W. Carroll, Melvin A. Eisenberg, Robert C. Ellickson, Julius G. Getman, Stephen J. Morse, Richard A. Posner, Margaret Jane Radin, Robert E. Scott, and Louis L. Wilde also made helpful comments on prior drafts.

1. See, e.g., U.C.C. $\$ 1-106(1)$ (1972 version) ("remedies . . . shall be liberally administered to the end that the aggrieved party may be put in as good a position as if the other party had fully performed. . . ."); Restatement of Contracts $§ 329$ (1932) (same) [hereinafter cited as Restatement].

2. See, e.g., R. Posner, Economic Analysis of Law 88-89 (2d ed. 1977) (defending current law on efficiency grounds); Kronman, Specific Performance, 45 U. CHI. L. REv. 351 (1978) (same); Farnsworth, Damages and Specific Relief, 27 Ам. J. Сoмp. L. 247 (1979). The only modern commentator to criticize specific performance law seriously is Professor Dawson, who has called for the specific performance of all contracts to deliver chattels. See Dawson, Specific Performance in France and Germany, 57 Mich. L. REv. 495, 532 (1959). Professor Dawson, however, did not deal with efficiency objections to the wider availability of specific performance. 
ing the availability of specific performance would not unduly restrict the liberty interests of promisors. Finally, Part $\mathrm{V}$ argues that defenses not available in an action for damages should be eliminated or severely restricted in their application to actions for specific performance. ${ }^{3}$

\section{The Current Law Regarding Specific Performance}

Under current law, courts grant specific performance when they perceive that damages will be inadequate compensation. Specific performance is deemed an extraordinary remedy, awarded at the court's discretion:

[I]t must be remembered that specific performance is not a matter of right, even when the plaintiff's evidence establishes a contract valid at law and sufficient for the recovery of damages. Ordering specific enforcement of a contract is a matter within the sound judicial discretion of the court. ... [T] required to show the good faith and equities of its own position, and the trial chancellor, in weighing the equities, was entitled to consider whether a decree of specific performance would work an unconscionable advantage to the plaintiff or would result in injustice. ${ }^{4}$

The paradigm cases in which the specific performance remedy is currently granted include sales of "unique goods," 5 in which substitutional damages are difficult to compute; sales of land, because land is

3. This Article omits consideration of several interesting facets of the specific performance question. First, a personal services contract is enforced by an injunction preventing the promisor from performing elsewhere rather than by an injunction requiring the promisor to perform. See Restatement $\$ 379$. This rule rests partly on the difficulty of supervising the promisor's performance, but primarily on the promisor's liberty interest in not being compelled to work at a particular job. See pp. 296-97 infra. Second, contracts in a family context, such as separation agreements, are sometimes specifically enforceable. Third, a seller usually cannot obtain specific performance of the price if the buyer has not accepted the goods, whereas vendors of land can sue for the price of unaccepted property. This Article does not analyze sellers' remedies; its concern is with cases in which the purchasers of goods, realty or services sue for specific performance. Fourth, expanding specific performance may raise questions concerning the availability of jury trials because suits for specific performance may be regarded as actions in equity.

4. Public Water Supply Dist. v. Fowlkes, 407 S.W.2d 642, 647 (Mo. App. 1966); accord, Green, Inc. v. Smith, 40 Ohio App. 2d 30, 39, 317 N.E.2d 227, 233 (1974). The current Restatement retains this rule. See Restatement (Second) of Contracts $\$ 371$ (1) (Tent. Draft No. 14, 1979) ("[S]pecific performance of a contract duty will be granted in the discretion of the court against a party who has committed or is threatening to commit a breach of the duty") [hereinafter cited as Restatement (SECOND)].

5. See, e.g., Leasco Corp. v. Taussig, 473 F.2d 777, 786 (2d Cir. 1972) (specifically enforcing contract for sale of business as each business is deemed unique); U.C.C. $\$ 2-716(1)$ (" [s]pecific performance may be decreed where the goods are unique or in other proper circumstances"). 
presumed unique; ${ }^{6}$ and, more recently, long-term requirements contracts, for which damages from breach are hard to calculate. ${ }^{7}$

A disappointed promisee who is able to show that he has no adequate remedy at law nevertheless is not assured of obtaining specific performance. Promisors can raise a number of defenses against specific performance that are not available against a damages award: inadequacy of consideration; ${ }^{8}$ lack of security for the promisee's performance; ${ }^{9}$ the promisor's unilateral mistake; ${ }^{10}$ and the difficulty a court would have in supervising a specific performance decree. ${ }^{11}$ These defenses serve to restrict further the availability of the specific performance remedy.

Further, courts currently refuse to enforce contracts providing for remedies different from those that they would grant. Liquidated damage clauses with sufficiently high damage provisions would in effect guarantee performance by the promisor because the costs to him of breach would always exceed the costs of performance. However, courts will not enforce such clauses; liquidated damage clauses are enforced only if they reflect a "reasonable" forecast of "actual" damages-the damages courts would grant if there were no liquidated damage clauses in the contracts. ${ }^{12}$ In addition, courts seldom enforce contract

6. See, e.g., Henderson v. Fisher, 236 Cal. App. 2d 468, 473, 46 Cal. Rptr. 173, 177 (1965); Gethsemane Lutheran Church v. Zacho, 258 Minn. 438, 443, 104 N.W.2d 645, 648 (1960).

7. See, e.g., Laclede Gas Co. v. Amoco Oil Co., 522 F.2d 33, 40 (8th Cir. 1975); Eastern Air Lines, Inc. v. Gulf Oil Corp., 415 F. Supp. 429, 442-43 (S.D. Fla. 1975); cf. U.C.C. $\S 2-716$ (Comment 2) (requirements contracts considered "unique goods").

8. See, e.g., Loeb v. Wilson, 253 Cal. App. 2d 383, 388, 61 Cal. Rptr. 377, 380 (1967); Schlegel v. Moorhead, 170 Mont. 391, 553 P.2d 1009 (1976); Restatement (Second) § $378(1)(c)$. But see note 78 infra (citing cases in which specific performance granted despite inadequacy of consideration). In some states, this defense is statutory. See, e.g., CaL. Civ. Code $\$ 3391.1$ (West 1970). Some state courts allow the defense only if the inadequacy is so great as to constitute fraud. See, e.g., Shepard v. Dick, 203 Kan. 164, 169, 453 P.2d 134, 138 (1969); Banner v. Elm, 251 Md. 694, 697, 248 A.2d 452, 453 (1968). For a criticism of this more stringent form of the defense, see J. Pomeroy, Treatise on the Specific Performance of Contracts 504-07 (3d ed. 1926) (stringent form of defense of little additional help to courts in deciding when to deny the remedy).

9. See, e.g., Rego v. Decker, 482 P.2d 834, 837-38 (Alaska 1971); Handy v. Gordon, 65 Cal. 2d 578, 422 P.2d 329, 55 Cal. Rptr. 769 (1967); Restatement (Second) $\$ 377$.

10. See, e.g., 4500 Suitland Rd. Corp. v. Ciccarello, 269 Md. 444, 452, 306 A.2d 512, 516 (1973); Public Water Supply Dist. v. Fowlkes, 407 S.W.2d 642, 649 (Mo. App. 1966).

11. See, e.g., Ryan v. Ocean Twelve, Inc., 316 A.2d 573, 575 (Del. Ch. 1973); Yonan v. Oak Park Fed. Sav. \& Loan Ass'n, 27 Ill. App. 3d 967, 974, 326 N.E.2d 773, 779 (1975).

12. See, e.g., Wise v. United States, 249 U.S. 361 (1919) (enforcing liquidated damage clause because not disproportionate to property loss); J. Weinstein \& Sons, Inc. v. City of New York, 264 App. Div. 398, 35 N.Y.S.2d 530, aff'd, 289 N.Y. 741, 46 N.E.2d 351 (1942) (striking down liquidated damages clause as out of proportion to probable damage); U.C.C. $\S 2-718(1)$; C. McCoRmick, LAW oF DAMAges $\S 149$ (1935). Recent commentators have persuasively criticized these restrictions on the use of liquidated damage clauses. See Goetz \& Scott, Liquidated Damages, Penalties and the Just Compensation Principle: Some Notes on an Enforcement Model and a Theory of Efficient Breach, 77 Colum. L. Rev. 554 (1977) (all liquidated damage clauses should be enforceable); Note, $A$ Critique of the Penalty Limitation on Liquidated Damages, 50 S. CaL. L. Rev. 1055 (1977) (same). 
clauses that provide explicitly for specific performance in the event of breach. ${ }^{13}$

\section{Contract Remedies and the Compensation Goal}

Specific performance is the most accurate method of achieving the compensation goal of contract remedies because it gives the promisee the precise performance that he purchased. ${ }^{14}$ The natural question, then, is why specific performance is not routinely available. ${ }^{15}$ Three explanations of the law's restrictions on specific performance are possible. First, the law's commitment to the compensation goal may be less than complete; restricting specific performance may reflect an inarticulate reluctance to pursue the compensation goal fully. Second, damages may generally be fully compensatory. In that event, expanding the availability of specific performance would create opportunities for promisees to exploit promisors by threatening to compel, or actually compelling, performance, without furthering the compensation goal. The third explanation is that concerns of efficiency or liberty may justify restricting specific performance, despite its greater accuracy; specific performance might generate higher transaction costs than the damage remedy, or interfere more with the liberty interests of promisors. The first justification is beyond the scope of the analysis here. ${ }^{16}$ The second and third explanations will be examined in detail.

With respect to the second justification, current doctrine authorizes

13. See, e.g., Stokes v. Moore, 262 Ala. 59, 77 So. 2d 331 (1955); Snell v. Mitchell, 65 Me. 48 (1876). For criticism of this rule, see Kronman, supra note 2, at 371-76; Macneil Power of Contract and Agreed Remedies, 47 CoRnell L.Q. 495, 520-23 (1962).

14. Admittedly, the equitable remedy does not compensate for the costs of legal delay; however, such delay is also a feature of actions for damages. Also, inflation partially offsets the costs of delay for promisees because it enables them to pay in cheaper dollars.

15. One of the earliest English royal writs available to promisees in contract, the writ of covenant, routinely provided for specific performance. See A. Simpson, A History of THE CoMmon LAW of Contract 14 (1975) ("[i]n common with other early writs the writ of covenant ... seems to be designed not so much to initiate proceedings directed towards compensating the plaintiff for wrong done, as to ensure that what was wrong should be put right. . . ."). By 1260 , however, damages had become the usual remedy in covenant.

Thereafter, courts of law were authorized only to give damage awards, id. at 595; courts of equity issued specific performance decrees, but only if there was no adequate remedy at law, id. at 596. With the merging of law and equity courts into a unified judicial system, the question arises whether continued restrictions on the availability of specific performance are still justified.

16. This Article's conclusion that specific performance should be made routinely available presupposes the desirability of the compensation goal. To deal fully with the claim that courts should not pursue the compensation goal fully, it would be necessary to formulate both a descriptive theory of why contracts are breached and a normative theory assessing the reasons for breach in terms of the underlying goals of contract law. Neither theory exists at present and creating them is beyond the scope of this Article. 
specific performance when courts cannot calculate compensatory damages with even a rough degree of accuracy. ${ }^{17}$ If the class of cases in which there are difficulties in computing damages corresponds closely to the class of cases in which specific performance is now granted, expanding the availability of specific performance is obviously unnecessary. Further, such an expansion would create opportunities for promisees to exploit promisors. The class of cases in which damage awards fail to compensate promisees adequately is, however, broader than the class of cases in which specific performance is now granted. Thus the compensation goal supports removing rather than retaining present restrictions on the availability of specific performance.

It is useful to begin by examining the paradigm case for granting specific performance under current law, the case of unique goods. ${ }^{18}$ When a promisor breaches and the promisee can make a transaction that substitutes for the performance the promisor failed to render, the promisee will be fully compensated if he receives the additional amount necessary to purchase the substitute plus the costs of making a second transaction. In some cases, however, such as those involving works of art, courts cannot identify which transactions the promisee would regard as substitutes because that information often is in the exclusive possession of the promisee. Moreover, it is difficult for a court to assess the accuracy of a promisee's claim. For example, if the promisor breaches a contract to sell a rare emerald, the promisee may claim that only the Hope Diamond would give him equal satisfaction, and thus may sue for the price difference between the emerald and the diamond. It would be difficult for a court to know whether this claim is true. If the court seeks to award money damages, it has three choices: granting the price differential, which may overcompensate the promisee; granting the dollar value of the promisee's foregone satisfaction as estimated by the court, which may overcompensate or undercompensate; or granting restitution of any sums paid, which undercompensates the promisee. The promisee is fully compensated without risk of overcompensation or undercompensation if the remedy of specific performance is available to him and its use encouraged by the doctrine that damages must be foreseeable and certain. ${ }^{19}$

If specific performance is the appropriate remedy in such cases, there

17. See pp. 272-73 and notes 5-7 supra.

18. See, e.g., Copylease Corp. of America v. Memorex Corp., 408 F. Supp. 758, 759 (S.D.N.Y. 1976) (unique goods contracts are exception to general rule limiting availability of specific performance); U.C.C. $\S 2-716(1)$ (buyer has right to specific performance in unique goods case).

19. For a fuller exposition of this argument, see Kronman, supra note 2, at 355-65. 
are three reasons why it should be routinely available. The first reason is that in many cases damages actually are undercompensatory. Although promisees are entitled to incidental damages, ${ }^{20}$ such damages are difficult to monetize. They consist primarily of the costs of finding and making a second deal, which generally involve the expenditure of time rather than cash; attaching a dollar value to such opportunity costs is quite difficult. Breach can also cause frustration and anger, especially in a consumer context, but these costs also are not recoverable. $^{21}$

Substitution damages, the court's estimate of the amount the promisee needs to purchase an adequate substitute, also may be inaccurate in many cases less dramatic than the emerald hypothetical discussed above. This is largely because of product differentiation and early obsolescence. As product differentiation becomes more common, the supply of products that will substitute precisely for the promisor's performance is reduced. For example, even during the period when there is an abundant supply of new Datsuns for sale, two-door, two-tone Datsuns with mag wheels, stereo, and air conditioning may be scarce in some local markets. Moreover, early obsolescence gives the promisee a short time in which to make a substitute purchase. If the promisor breaches late in a model year, for example, it may be difficult for the promisee to buy the exact model he wanted. For these reasons, a damage award meant to enable a promisee to purchase "another car" could be undercompensatory.

In addition, problems of prediction often make it difficult to put a promisee in the position where he would have been had his promisor performed. ${ }^{22}$ If a breach by a contractor would significantly delay or prevent completion of a construction project and the project differs in important respects from other projects-for example, a department store in a different location than previous stores-courts may be reluctant to award "speculative" lost profits attributable to the breach. ${ }^{23}$

20. E.g., U.C.C. $\S 2-715(1)$.

21. Emotional distress caused by a breach, which does not in itself constitute a tort, ordinarily is not recoverable in damages. See, e.g., Jankowski v. Mazzotta, 7 Mich. App. $483,486,152$ N.W.2d 49, 50-51 (1967) (damages for mental anguish limited to cases involving "reckless misconduct" or contracts "inherently personal in nature").

22. The difficulties of prediction have been recognized for some time. See, e.g., RESTATEMENT $\$ 329$, Comment a (difficulties involved in awarding compensatory damages "make it impracticable to attain its purpose with any near approach to exactness"); W. WALSh, A Treatise on EQuiry 300 (1930) (damages at best only substitute for what plaintiff lost through loss of performance).

23. See, e.g., Fredonia Broadcasting Corp. v. RCA Corp., 481 F.2d 781, 802-04 (5th Cir. 1973) (future profits of new business deemed too speculative for inclusion in damages); Atomic Fuel Extraction Corp. v. Slick's Estate, 386 S.W.2d 180, 189-90 (Tex. Civ. App. 1965) (same). 
Second, promisees have economic incentives to sue for damages when damages are likely to be fully compensatory. A breaching promisor is reluctant to perform and may be hostile. This makes specific performance an unattractive remedy in cases in which the promisor's performance is complex, because the promisor is more likely to render a defective performance when that performance is coerced, and the defectiveness of complex performances is sometimes difficult to establish in court. Further, when the promisor's performance must be rendered over time, as in construction or requirements contracts, it is costly for the promisee to monitor a reluctant promisor's conduct. If the damage remedy is compensatory, the promisee would prefer it to incurring these monitoring costs. Finally, given the time necessary to resolve lawsuits, promisees would commonly prefer to make substitute transactions promptly and sue later for damages rather than hold their affairs in suspension while awaiting equitable relief. The very fact that a promisee requests specific performance thus implies that damages are an inadequate remedy. ${ }^{24}$

The third reason why courts should permit promisees to elect routinely the remedy of specific performance is that promisees possess better information than courts as to both the adequacy of damages and the difficulties of coercing performance. Promisees know better than courts whether the damages a court is likely to award would be adequate because promisees are more familiar with the costs that breach imposes on them. In addition, promisees generally know more about their promisors than do courts; thus they are in a better position to predict whether specific performance decrees would induce their promisors to render satisfactory performances.

In sum, restrictions on the availability of specific performance cannot be justified on the basis that damage awards are usually compensatory. On the contrary, the compensation goal implies that specific performance should be routinely available. This is because damage awards actually are undercompensatory in more cases than is commonly supposed; the fact of a specific performance request is itself good evidence that damages would be inadequate; and courts should delegate to promisees the decision of which remedy best satisfies the compensation goal. Further, expanding the availability of specific per-

24. Noneconomic motives could sometimes impel a promisee to seek specific performance; the German experience, however, provides some confirmation of this point. Although specific performance is much more widely available in Germany than in the United States, promisees there seek the damage remedy "in a high percentage of cases." Dawson, supra note 2, at 530; see Treitel, Remedies for Breach of Contract, in VII International Encyclopedia of Comparative Law 16-17 to 16-29 (1976) (claims for damages "more common" than claims for specific performance). 
formance would not result in greater exploitation of promisors. Promisees would seldom abuse the power to determine when specific performance should be awarded because of the strong incentives that promisees face to seek damages when these would be even approximately compensatory.

\section{Specific Performance and Efficiency}

Before examining in detail the efficiency justifications that could be given for restricting specific performance, it will be useful to relate these justifications to the possible bases of the compensation goal. First, suppose that the goal rests on utilitarian or wealth maximization grounds, ${ }^{25}$ that is, on an assumption that compensating disappointed promisees fully is less costly than not compensating them fully. If the broader availability of specific performance would generate transaction costs that exceed the costs of undercompensation the equitable remedy would avoid, then current restrictions on specific performance would be justified. On the other hand, if the compensation goal rests on a moral notion that promises should be kept, ${ }^{26}$ that contract remedies should effectuate the state of affairs-performance-that the promisor has a duty to bring about and that the promisee has a right to have brought about, then specific performance is a preferable remedy to damages even though it might generate higher costs. These costs would be the price of achieving the moral goal of contract remedies. Under this theory, the promisee's right to an actual performance should be overridden only if the costs of its exercise would be so excessive as to constitute an interference with the rights of other persons.

Both possible bases of the compensation goal thus would support the routine availability of specific performance unless specific per-

25. Professor Posner recently argued that a nonutilitarian version of consequentialism which he calls wealth maximization underlies and justifies much current law. See Posner, Utilitarianism, Economics, and Legal Theory, 8 J. Legal Stud. 103 (1979). According to Posner, a legal rule (indeed, all conduct) is good if it increases society's wealth, bad if it reduces that wealth.

26. For an introduction to how a moral justification for promise-keeping can be made, see J. Mackie, Ethics 110-11, 116-18, 184-85 (1977). Professor Mackie's argument, derived from Hobbes and Hume, is that it in a promisor's self-interest to keep his word. A similar argument may follow from Kantian premises. Kant uses promise-keeping as one of his four illustrations of the categorical imperative:

For the universality of a law that everyone believing himself to be in need can make any promise he pleases with the intention not to keep it would make promising, and the very purpose of promising, itself impossible, since no one would believe he was being promised anything, but would laugh at utterances of this kind as empty shams.

I. Kant, Groundwork of the Metaphysic of Morals 90 (H. Paton trans. 1964). 
formance is a more costly remedy than damages. There are two principal ways in which efficiency might suffer as the result of expanding specific performance. First, many parties might prefer to have the specific performance remedy available only in those cases in which the law currently grants it. If the remedy's availability were greatly expanded, these parties would negotiate contract provisions restricting its use. Legal limitations on the availability of specific performance save these transaction costs. Professor Anthony Kronman has argued that limiting specific performance is justified precisely because it avoids such "prebreach" negotiations. ${ }^{27}$ Second, if specific performance were routinely available, promisors who wanted to breach would often be compelled to "bribe" promisees to release them from their obligations. The negotiations required might be more complex and costly than the post-breach negotiations that occur when breaching promisors have merely to pay promisees their damages. Professor Richard Posner argues, therefore, that restricting specific performance reduces "postbreach" negotiation costs. ${ }^{28}$ Part III considers these two arguments in detail, as well as other efficiency aspects of the choice between specific performance and damages.

\section{A. Pre-Breach Negotiations}

"Intention justification" theories for restricting specific performance argue that the class of cases in which the parties now can get the remedy, and the class of cases in which the parties would want the remedy to be available, are coextensive. There are two difficulties with this position. First, there is no reason to assume that the parties' preferences are congruent with current law. Second, it is excessively difficult to derive from parties' preferences general legal rules respecting when either remedy should be used.

Both weaknesses are illustrated through an analysis of the most sophisticated intention justification theory, that of Professor Kronman.

27. Kronman, supra note 2 , at 365-69.

28. R. Posner, supra note 2, at 88-89. Other commentators have made similar arguments. See Clarkson, Miller, \& Muris, Liquidated Damages v. Penalties: Sense or Nonsense? 1978 Wis. L. REv. 351, 360 n.32. Professor Farnsworth recently criticized the specific performance remedy on the apparently distinct ground that specific relief prevents a promisor from reallocating his resources to higher valued uses even though substitutional relief would be fully compensatory to the promisee. Farnsworth, supra note 2, at 250-51. This criticism is incorrect because promisors can reallocate their resources-i.e., breachby bribing promisees not to seek specific relief. Thus Farnsworth's position reduces to the claim that Posner makes, that the transaction costs entailed in these post-breach negotiations would be higher than the transaction costs that now obtain under the damage remedy. 
Kronman classifies as "unique" those objects for which courts would have great difficulty identifying substitutes. Courts today generally limit specific performance to such cases. Professor Kronman argues that this limitation is consistent with the parties' intentions; if they were to contract as to remedy in the absence of a general rule, they would create a specific performance remedy only for sales of "unique" goods or services. Kronman's argument starts from the premise that the "cost of a specific performance provision to the promisor will be determined, in part, by his own estimate of the likelihood that he will want to breach the contract." ${ }^{29}$ This likelihood is primarily a function of "the probability that he will receive a better offer for his goods or services in the interim between formation of the contract and performance." 30 This probability is low "where the subject matter of the contract is unique" because "there is by definition no developed market [and] transactions are spotty at best. ..." 31 In situations in which the subject matter of the contract is not unique, "by contrast, the existence of a developed market increases the likelihood that the promisor will receive alternative offers before he has performed the contract." 32 The promisee in the unique goods case may doubt whether the promisor will actually perform, despite the unlikelihood that the promisor will receive a better offer. Since damage remedies could be undercompensatory, the promisee would probably prefer to have the specific performance remedy available..$^{33}$ When the goods are not unique, however, the promisee regards the "risk [of undercompensation] as slight where there is a developed market generating information about suitable substitutes." ${ }^{34}$ Thus in the unique goods case the parties would be expected to agree to a specific performance remedy; the promisee wants the remedy, whereas the promisor is indifferent. In the nonunique goods case, on the other hand, the parties would probably negotiate for a damage remedy, because damages would adequately protect the promisee, while the promisor would want to be free to accept more favorable offers.

Analysis of the equilibria in "developed" and "undeveloped markets" and their reactions to exogenous shocks suggests, however, that the promisors of unique goods care more about retaining the option of breach than do promisors of nonunique goods. Respecting equilibria,

29. Kronman, supra note 2, at 367.

30. Id. at 368.

31. Id.

32. Id.

33. Id.

34. Id. at 369 . The risk of undercompensation, however, actually may be substantial even when "developed" markets exist. See pp. 275-76 supra. 
Professor Kronman equates an undeveloped market with a market in which unique goods are sold. This is misleading because unique goods markets often are well organized; the antique market provides an example. Such markets have two distinguishing features. First, they are usually characterized by greater price dispersion than obtains in the market equilibria for roughly fungible goods. In addition, sellers of unique goods face a lower "rate of arrival" of potential buyers than do sellers of roughly fungible goods. These two phenomena are related; a high "buyer arrival" rate implies extensive comparison shopping among firms, whereas the degree of price dispersion a market can sustain varies inversely with the amount of comparison shopping. ${ }^{35}$ Sellers of unique goods face a relatively low buyer arrival rate because each item they sell is highly differentiated; consequently, relatively few potential customers for such items exist. Also, search costs are comparatively higher for unique goods; locating them can be difficult, and the sellers often are geographically dispersed. Further, analyzing the quality of particular unique goods and comparing different goods usually are more time-consuming than searching for roughly fungible goods.

A promisor/seller in an "undeveloped market"-a market in which unique goods are sold-thus faces a lower arrival rate of potential buyers together with the resultant higher degree of price dispersion than a promisor in a developed market. The promisor of unique goods consequently has grounds to believe that the offers he receives are to some extent random, and that later offers could be much higher than earlier ones. This promisor thus prefers damages to specific performance because the damages remedy preserves his freedom to breach.

This conclusion is reinforced by an examination of the differing reactions of "developed" and "undeveloped" markets to exogenous shocks. ${ }^{36}$ Exogenous shocks help to explain why promisors might receive better offers between the time they contract and the time they are supposed to render performance. This phenomenon needs explanation because a vendor of goods or services is generally assumed to sell

35. See Schwartz \& Wilde, Intervening In Markets on the Basis of Imperfect Information: A Legal and Economic Analysis, 127 U. PA. L. REv. 630, 640-51 (1979).

36. Economists draw a distinction between the factors influencing market equilibria that are intrinsic to the market ("endogenous" factors) and those that are extrinsic to it ("exogenous" factors). An example of an endogenous factor is the strategies that consumers use in acquiring purchase information; market equilibria are partly a function of the information-gathering strategies of consumers. An example of an exogenous factor is an embargo; a particular equilibrium will be disturbed if an embargo reduces available supply. For a discussion of the contributions of endogenous and exogenous factors to the character of market equilibria in an information-gathering context, see Rothschild, Models of Market Organization with Imperfect Information: A Survey, 81 J. Pol. Econ. 1283 (1973). 
to all of his purchasers on the same terms. Price discrimination is often unlawful and its costs in mass transactions exceed the gains it produces. $^{37}$ Customers generally know whether a firm offers the same terms to all and are unlikely to make offers that exceed the going price. In addition, firms that negotiate contracts on an individual basis have a strong incentive not to breach, even if they receive better offers, in order to maintain goodwill. ${ }^{38}$ In what circumstances, then, will promisors receive and accept better offers?

The most frequent situation in which these circumstances arise is when there is an unexpected and dramatic increase in demand. The increase in demand will exert an upward pressure on prices. In the case of nonunique goods, this pressure is partially relieved by the ability of sellers to increase output. Unique goods, however, are in inelastic supply; only a few Rembrandts exist, and an increase in demand will not increase their number. ${ }^{39}$ In consequence, when buyers demand more of a unique item, the primary response of sellers is to increase the price; they can expand output only slightly, if at all.40

37. Schwartz \& Wilde, supra note 35 , at $638,663-65$.

38. The desire of firms to preserve goodwill is evident in the existence of two common retail practices: marking items "sold" and holding them for the original purchasers rather than reselling them to subsequent buyers at higher prices, and, in the case of firms that sell services, rationing temporary excess demand by queuing rather than by selling services to subsequent customers at increased rates.

39. For a more rigorous discussion of the theory of supply elasticity, see P. SAMUeLson, Economics 386-87 (10th ed. 1976).

40. The argument in text can be clarified by a diagram.

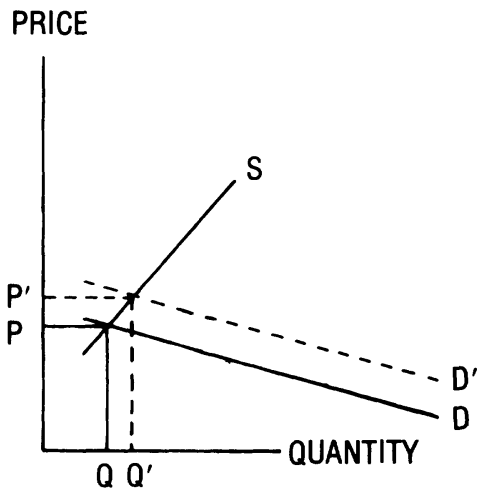

FIGURE I

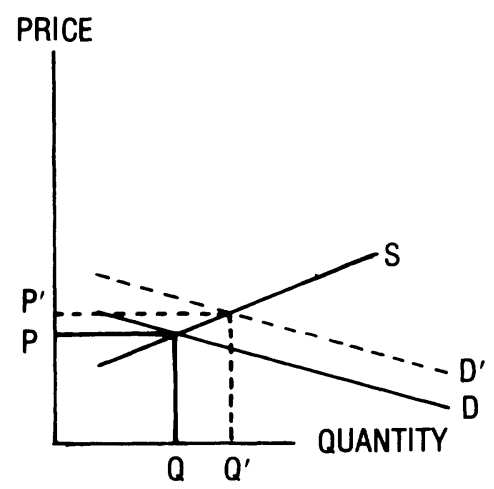

FIGURE ॥

In both figures, an increase in demand is represented by a similar shift in the demand curve from $D$ to $D^{\prime}$. In Figure 1, however, supply (S) is inelastic; no matter how great the shift in demand, little more of the good is supplied. Thus almost the full force of the demand shift is translated into the price increase. In Figure 2, supply is elastic, so that output expands considerably and the price increase is more moderate. 
Therefore, when demand unexpectedly increases, a promisor in a unique goods market could command higher prices than a promisor in a nonunique goods market. The seller of unique goods, when the contract is negotiated, thus has a strong incentive to preserve his freedom to breach. A seller of nonunique goods, by contrast, will probably have to compete with many other vendors for any new business that a demand increase generates, and the resultant price rise will be relatively modest. Thus he will care less about preserving his freedom to breach in response to demand shifts. ${ }^{41}$ In sum, if the promisor's preference for specific performance or damages is assumed to be determined solely by whether the performance at issue is unique, the promisor would not choose specific performance in situations in which the law now routinely grants it. ${ }^{42}$

In addition, considerations exist that could lead promisees not to prefer a right to specific performance in cases in which it is currently available and to seek this right in situations in which it is not now granted.43 Purchasers of houses or land, for example, may sometimes

41. This analysis applies not only to goods that have traditionally been considered unique but also to goods that are currently in inelastic supply. Prices also will rise if demand remains constant and supply contracts. Provided the demand curve remains constant, the suppliers of unique and nonunique goods will be similarly affected, and thus have similar incentives to preserve their freedom to breach.

42. Confirming the textual analysis that shifts in demand affect preferences for specific performance, a number of recent suits for specific performance seem to have been caused in part by shifts in demand, e.g., Weathersby v. Gore, 556 F.2d 1247, 1249 (5th Cir. 1977) (cotton); Tower City Grain Co. v. Richman, 232 N.W.2d 61, 63 (N.D. 1975) (boxcar shortage suggests increased demand for grain); or combinations of shifts in demand and supply, e.g., Laclede Gas Co. v. Amoco Oil Co., 522 F.2d 33, 36 (8th Cir. 1975) (propane gas); Eastern Air Lines, Inc. v. Gulf Oil Corp., 415 F. Supp. 429, 441 (S.D. Fla. 1975) (jet fuel).

43. The cheapest cost-avoider technique, see G. Calabresi, The Cost of Accidents 135-40 (1970), provides an alternative means of analyzing the parties' intentions respecting remedy provisions in unique goods transactions. The relevant risk is that the promisor/seller will get a better offer in the interval between contract formation and performance time. If the seller bears this risk, he must perform despite the better offer; if the buyer bears the risk, the seller is free to take the better offer and pay damages to the first buyer. The seller, this analysis assumes, is the cheapest cost-avoider of the risk of receiving a better offer because he generally has superior knowledge of market conditions. Since the parties will typically negotiate to put the risk on the cheapest costavoider, they would normally contract for a specific performance remedy in the unique goods case. Professor Kronman does not make this argument, and he may be right not to do so because generalizations about whether promisors or promisees have superior ability to predict the future are too difficult to make. For example, an individual selling an heirloom to a dealer would probably have less knowledge than the dealer; a dealer selling to a consumer would probably have more knowledge than the consumer; and a wholesale antique dealer selling to a retail dealer would probably have no more knowledge than this buyer. Thus it is incorrect to argue that parties commonly would negotiate for a specific performance remedy in the unique goods case; such an argument must rest on the unproven assertion that promisors have a comparative advantage at predicting the future. 
prefer liquidated damage clauses to specific performance because sellers in possession during the specific performance action might cause damage that would be difficult to prove in court. Also, a purchaser of a unique good may prefer damages to specific performance if he believes that he could later persuade a court to accept his exaggerated claim as to the cost of an adequate substitute. Promisees of nonunique goods, on the other hand, may prefer specific performance because large damage judgments can be difficult to obtain or satisfy. ${ }^{44}$

Thus no single factor-such as the uniqueness of the performancewill determine the parties' preferences as to remedy in all cases, for the parties' preferences are context-dependent. Further analysis would probably suggest additional discrepancies between the remedies the parties desire in specific situations and those the law now provides. The costs of tailoring the law to the parties' preferences on a case-by-case basis, however, would exceed the gains. As with an attempt to draft substantive contract clauses, a great number of rules would have to be devised. Therefore, because it has not been established that restricting specific performance minimizes transaction costs of negotiating remedies, and tailoring remedies to the parties' preferences would be so costly administratively, intention justification theories should be abandoned as guides to remedy availability. Rather, specific performance should be made generally available on the ground that the compensation goal is not met adequately by making damages the sole available remedy in many cases. This recommendation presupposes, however, that the post-breach negotiation costs thereby generated would not exceed those generated under current law. This presupposition must be analyzed next.

\section{B. Post-Breach Negotiations}

The second efficiency argument for restricting the availability of specific performance is that making specific performance freely avail-

44. For example, some cotton purchasers unsuccessfully sought specific performance of contracts that their grower-sellers had breached when cotton prices tripled between the time the contract was negotiated and the time for performance. The buyers may have believed that local juries might be reluctant to award large damages against local farmer defendants. See Weathersby v. Gore, 556 F.2d 1247 (5th Cir. 1977); Duval \& Co. v. Malcom, 233 Ga. 784, 214 S.E.2d 356 (1975).

The Restatement lists "the degree of probability that damages awarded cannot in fact be collected" as a factor to be considered in "determining the adequacy of the remedy in damages." Restatement $\$ 361(\mathrm{~d})$; accord, Restatement (SeCond) $\$ 374(\mathrm{c})$. See Severson v. Elberon Elevator, Inc., 250 N.W.2d 417, 423 (Iowa 1977) (defendant's financial straits relevant to specific performance request). The unlikelihood of collecting a damage award would of course justify specific performance regardless of whether the goods were "unique." 
able would generate higher post-breach negotiation costs than the damage remedy now generates. For example, suppose that a buyer (Bl) contracts with a seller (S) to buy a widget for $\$ 100$. Prior to delivery, demand unexpectedly increases. The widget market is temporarily in disequilibrium as buyers make offers at different prices. While the market is in disequilibrium, a second buyer (B2) makes a contract with $S$ to purchase the same widget for $\$ 130$. Subsequently, the new equilibrium price for widgets is $\$ 115$. If specific performance is available in this case, $\mathrm{Bl}$ is likely to demand it, in order to compel $\mathrm{S}$ to pay him some of the profit that $S$ will make from breaching. Bl could, for example, insist on specific performance unless $S$ pays him $\$ 20$ (\$15 in substitution damages plus a $\$ 5$ premium).$^{45}$ If $S$ agrees, $B 1$ can cover at $\$ 115,46$ and be better off by $\$ 5$ than he would have been under the damage remedy, which would have given him only the difference between the cover price and the contract price $(\$ 15)$. Whenever S's better offer is higher than the new market price, the seller has an incentive to breach, and the first buyer has an incentive to threaten specific performance in order to capture some of the seller's gains from breach.

The post-breach negotiations between $S$ and Bl represent a "deadweight" efficiency loss; the negotiations serve only to redistribute wealth between $S$ and Bl, without generating additional social wealth. If society is indifferent as to whether sellers or buyers as a group profit from an increase in demand, the law should seek to eliminate this efficiency loss. Limiting buyers to the damage remedy apparently does so by foreclosing post-breach negotiations.

This analysis is incomplete, however. Negotiation costs are also generated when $\mathrm{Bl}$ attempts to collect damages. If the negotiations by which first buyers (Bl here) capture a portion of their sellers' profits from breach are less costly than the negotiations (or lawsuits) by which first buyers recover the market contract differential, then specific performance would generate lower post-breach negotiation costs than damages. This seems unlikely, however. The difference between the contract and market prices is often easily determined, and breaching sellers have an incentive to pay it promptly so as not to have their extra profit consumed by lawyers' fees. By contrast, if buyers can threaten

45. B1 would not require $S$ to convey the widget to him for resale to $B 2$ at $\$ 130$ because if $\mathrm{S}$ breached his contract with $\mathrm{B} 2, \mathrm{~B} 2$ would then buy a widget in the open market for $\$ 115$. Only $S$ can sell to $B 2$ at $\$ 130$, because $B 2$ has contracted only with $S$ to purchase at that price.

46. To "cover" is to make a substitute purchase. See U.C.C. $\S 2-712(1)$. "Cover costs" refer not to the price paid for the substitute, but rather to the costs incurred in locating the substitute and making a second transaction. 
specific performance and thereby seek to capture some of the sellers' profits from breach, sellers will bargain hard to keep as much of the profits as they can. Therefore, the damage remedy would probably result in quick payments by breaching sellers while the specific performance remedy would probably give rise to difficult negotiations. ${ }^{47}$ Thus the post-breach negotiation costs associated with the specific performance remedy would seem to be greater than those associated with the damage remedy. ${ }^{48}$

This analysis makes the crucial assumption, however, that the first buyer, Bl, has access to the market at a significantly lower cost than the seller; ${ }^{49}$ though both pay the same market price for the substitute, Bl is assumed to have much lower cover costs. If this assumption is false, specific performance would not give rise to post-breach negotiations. Consider the illustration again. Suppose that Bl can obtain specific performance, but that $\mathrm{S}$ can cover as conveniently as $\mathrm{Bl} 1 .^{50}$ If

47. Similarly, a liquidated damage clause with a very high payoff would also produce negotiations. This is because, if the clause is enforceable, the payoff would exceed any profit the promisor could realize from breach, but the promisee has an incentive to permit breach in return for a share of this profit. A commentator discussing the enforceability of these clauses has asserted that the transaction costs of negotiating over the profit would seem to be less than "the litigation or settlement costs of breach of contract" if the clauses were not enforceable. Note, Liquidated Damages and Penalties Under the Uniform Commercial Code and the Common Law: An Economic Analysis of Contract Damages, 72 Nw. U.L. REv. 1055, 1079 (1978). This fails to take into account the promisee's incentive to settle quickly when the legal damages are easily ascertainable and less than the profit. Other recent commentary suggests that the negotiation costs that might result from a liquidated damage clause with a high payoff "may not be merely nominal" because "there are no legal guidelines to provide a certain answer as to what" the seller must pay his initial buyer. Clarkson, Miller, \& Muris, supra note 28, at 362 n.34; cf. Ellickson, Alternatives to Zoning: Covenants, Nuisance Rules, and Fines as Land Use Controls, 40 U. CHI. L. REv. 681, 743-44 (1973) (negotiation costs are reduced when damage rules establish clear guidelines for bargaining).

48. The sales-law rule that prohibits sellers from obtaining specific performance, i.e., payment, for unaccepted goods can be explained in these terms. Under the current rule, the seller must resell the goods; otherwise, the rejecting buyer would have to resell them. Sellers are probably more efficient resellers than the rejecting buyers because selling is sometimes a specialized activity. Thus, if buyers were liable for the price, they would probably bribe sellers to resell the goods for them. Negotiation costs avoided under the current rule would thereby be generated. At present, the sellers resell the goods and proceed against the buyers to recover the market contract differential. If the resultant transaction costs are lower than those that would result from the buyers' attempts to bribe sellers to resell the goods, then the current rule is more efficient than granting sellers a price action. Because the market contract differential is easily determined while the appropriate bribe is not, it seems likely that the current rule is the more efficient one.

49. See R. POSNER, supra note 2, at 89.

50. When the contract between $S$ and $B 1$ involves the sale of goods, $S$ of course covers by purchasing similar goods in the market. When the contract involves services, $S$ covers by providing a delegate to render the promised performance. Buyers are required to accept the delegate unless the promisor's performance is in some sense unique. Compare Corson v. Lewis, 77 Neb. 446, 449, 109 N.W. 735, 736 (1906) (attorney's service to his client held nondelegable) with New England Iron Co. v. Gilbert Elevated R.R. Co., 91 N.Y. 153, 167-68 (1883) (construction contract duties delegable). See generally J. Calamari \& J. Perillo, Contracts 430-33 (1970). 
Bl insists on a conveyance, $\mathrm{S}$ would buy another widget in the market for $\$ 115$ and deliver on his contracts with both $\mathrm{Bl}$ and B2. A total of three transactions would result: S-B1; S-B2; S2-S (S's purchase of a second widget). None of these transactions involves post-breach negotiations. Thus if sellers can cover conveniently, the specific performance remedy does not generate post-breach negotiation costs.

The issue, then, is whether sellers and buyers generally have similar cover costs. Analysis suggests that they do. Sellers as well as buyers have incentives to learn market conditions. Because sellers have to "check the competition," they will have a good knowledge of market prices and quality ranges. Also, when a buyer needs goods or services tailored to his own needs, he will be able to find such goods or services more cheaply than sellers in general could, for they would first have to ascertain the buyer's needs before going into the market. However, in situations in which the seller and the first buyer have already negotiated a contract, the seller is likely to have as much information about the buyer's needs as the buyer has. Moreover, in some markets, such as those for complex machines and services, sellers are likely to have a comparative advantage over buyers in evaluating the probable quality of performance and thus would have lower cover costs. Therefore, no basis exists for assuming that buyers generally have significantly lower cover costs than sellers. It follows that expanding the availability of specific performance would not generate higher post-breach negotiation costs than the damage remedy.

Four serious objections may be made to this conclusion: (i) differential cover costs sometimes help induce breach, and their existence leads to higher post-breach negotiation costs under specific performance than under damages; (ii) in some cases, sellers cannot cover at all; (iii) when the first and second buyers have different uses for the subject of the sale, specific performance generates higher post-breach negotiation costs than damages; (iv) when changed circumstances occur-an important cause of breach-transaction costs are higher under specific performance than under damages.

The first objection assumes that sellers breach partly because their cover costs are higher than those of their buyers; it then argues that when cover costs do diverge, allowing specific performance seemingly is less efficient than having damages be the sole remedy. Returning to the widget hypothetical, let $\mathrm{Cb}=$ the first buyer's (Bl's) cover costs; $\mathrm{Cs}=$ the seller's cover costs. Assume that $\mathrm{S}$ has higher cover costs than $\mathrm{B} 1$, i.e., $\mathrm{Cs}>\mathrm{Cb}$. If specific performance were available, $\mathrm{B} 1$ could 
threaten to obtain it, so as to force $S$ to pay him part of the cover cost differential, $\mathrm{Cs}-\mathrm{Cb}$. If $\mathrm{Bl}$ made a credible threat, $\mathrm{S}$ would be better off negotiating than covering. Because only the availability of specific performance enables $\mathrm{Bl}$ to force this negotiation, one could argue that it is less efficient than having damages as the sole remedy.

This objection is incorrect, even if differential cover costs influence seller decisions to breach. A credible threat by Bl to seek specific performance would usually require preparing or initiating a lawsuit. This would entail costs of lost business time, lost goodwill and lawyer's fees, and these costs usually exceed any cover cost differential $(\mathrm{Cs}-\mathrm{Cb})$ that may exist. This is because the magnitude of cover costs-and hence of the differential-are low in relation to legal costs. Locating and arranging for substitute transactions are routine, relatively inexpensive business activities. Since the legal and related costs necessary for a credible threat commonly exceed the cover cost differential, it would rarely pay buyers to threaten specific performance to capture part of this differential. Thus no post-breach negotiations would be engendered by any differences in the parties' cover costs.

The second objection to the conclusion that post-breach negotiation costs are no higher under specific performance than under damages follows from the fact that in some cases sellers cannot cover at all. In these cases, buyers can always compel post-breach negotiations by threatening specific performance. There are two situations in which a seller cannot cover: if he is a monopolist or if the goods are unique. In either event, the first buyer would also be unable to cover. If neither the seller nor the first buyer can cover, no reason exists to believe that there would be higher post-breach negotiation costs with specific performance than with damages. If specific performance were available, $\mathrm{Bl}$ and S would negotiate over Bl's share of the profit that S's deal with B2 would generate, or B1 would insist on a conveyance from $S$ and then sell to B2. If only the damages remedy is available, B1 would negotiate with $\mathrm{S}$ respecting his expected net gain from performance rather than over the contract market difference, because he could not purchase a substitute. This expected gain is often difficult to calculate, and easy for the buyer to exaggerate. There is no reason to believe that negotiations or litigation over this gain would be less costly than the negotiations over division of the profit that B2's offer creates, or the costs of a second conveyance between $\mathrm{B} 1$ and B2. Thus even when the seller cannot cover, specific performance has not been shown to generate higher post-breach negotiation costs than damages. Moreover, 
when neither party can cover-the case under discussion-buyers have a right to specific performance under current law. ${ }^{51}$

To summarize, if the initial buyer has access to the market at a significantly lower cost than the seller, a damages rule generates lower post-breach negotiation costs than a rule that makes specific performance routinely available. It seems likely, however, that both parties will be able to cover at similar, relatively low cost, or that neither will be able to cover at all. In either event, post-breach negotiation costs are similar under the two rules. ${ }^{52}$

The third objection to this conclusion concerns cases in which the first and second buyers have different uses for the good for sale. If the good is in inelastic supply in one of those uses, allowing specific performance would be less efficient than only allowing a damages remedy. For example, suppose that $\mathrm{Bl}$ contracts to purchase property for use as a farm. B2 discovers that the land is an ideal location for a restaurant and persuades the seller to convey it to him at a much higher price than Bl agreed to pay. Both $B 1$ and S could probably cover respecting the first contract, for farmland is often fungible. Thus if a damage rule obtained, $\mathrm{S}$ would offer to convey a different parcel to $\mathrm{Bl}$ or pay $\mathrm{Bl}$ damages, and sell his own land, which is unique to B2's use, to B2. If Bl could get specific performance, however, two undesirable outcomes might occur. First, B1 may discover B2's purpose and insist on a conveyance to adopt B2's intended use. Thus B1 could freeload on the

51. See, e.g., U.C.C. $§ 2-716(1)$ (authorizing specific performance "where the goods are unique or in other proper circumstances.") Comment 2 to the provision provides that "inability to cover is strong evidence of "other proper circumstances." See Kaiser Trading Co. v. Associated Metals \& Minerals Corp., 321 F. Supp. 923, 932-33 (N.D. Cal. 1970), appeal dismissed, 443 F.2d 1364 (9th Cir. 1971); p. 275 supra.

When the seller is a monopolist, there would seem to be one case in which specific performance should be denied. Suppose that a monopolist contracts to sell widgets before his factory is destroyed by fire. If specific performance would lie, the buyer might attempt to extort the seller by threatening to obtain a specific performance order, for the seller could neither cover nor perform. Negotiations would result as to the sum the seller would pay to avoid being found in contempt. These negotiations would constitute a deadweight efficiency loss. See R. Posner, supra note 2, at 96-97. This outcome would not occur, however. When goods are to be delivered from a specified source and the source is destroyed by unanticipated casualty, the seller is excused from performing. See U.C.C. $\$ 2-615$, Comment 5 .

52. This analysis seems to overlook the buyer's duty to mitigate damages. Suppose that $S$ has significantly higher performance costs than the market as a whole, so that Bl could purchase a substitute for less than it would cost $S$ to perform. Should $S$ be able to assert his unusually high costs as a defense to an action for specific performance on the ground that Bl can mitigate S's damages by making a substitute purchase? The answer should be no for two reasons. First, this situation will rarely occur because $S$ can often cover as easily as B1, see p. 287 supra. Therefore the defense is largely unnecessary. Second, enabling $S$ to oppose an action for specific performance on the ground that his costs are relatively high would create a defense that would be costly to adjudicate, and could be unpredictable in application. 
information developed by $\mathrm{B} 2$, which would reduce the incentive of persons like B2 to discover new uses. Alternatively, B1 might either negotiate with $S$ to capture some of S's profit from breach, or insist on conveyance and resell the property to B2. Both alternatives could create transaction costs without generating new social wealth. On the other hand, if $\mathrm{Bl}$ could only recover from $\mathrm{S}$ the difference between the price of a similar piece of farmland and the contract price, transaction costs would be lower, because $S$ has strong incentives to cover or remit this sum voluntarily. ${ }^{53}$ Therefore, the damage remedy is more efficient than the specific performance remedy where the market provides substitutes for Bl's intended use of the property, but not for B2's intended use. Courts nevertheless currently allow specific performance in such cases. ${ }^{54}$ Thus the issue is whether, if specific performance were made routinely available, an exception should be created for the different-use case. The answer is no, because the litigation and uncertainty costs that the exception would generate would probably exceed the excess bargaining costs of making specific performance available in this relatively uncommon situation.

The final objection to the conclusion that post-breach negotiation costs are no higher under specific performance than under damages applies in the context of unexpectedly rapid inflation. Suppose that a promisee would realize $\$ 3,000$ profit from a construction project that he contracted to buy for $\$ 10,000$. Suppose also that, at the time he made the contract, the promisor anticipated that the project would cost him $\$ 8,000$, and that unanticipated inflation raised the promisor's costs to $\$ 15,000$. In the event that the promisee's anticipated profits from completion of the project do not similarly increase, the promisee's best strategy would be to threaten specific performance so as to force the promisor to share part of the $\$ 7,000$ cost savings that the promisor

53. See p. 285 supra.

54. The overwhelmingly popular rule is that "[s]pecific performance of a contract for the sale of land is generally granted even though the injury resulting from nonperformance is compensable in damages." Atchison v. City of Englewood, 568 P.2d 13, 22 (Colo. 1977). In a very few cases, courts have refused to grant specific performance of land contracts on the ground that money damages would adequately protect the promisee. See, e.g., Watkins v. Paul, 95 Idaho 499, 511 P.2d 781 (1973). When the vendor has sold to a subsequent good faith purchaser at a price considerably above the contract price, however, courts have occasionally refused to impose a constructive trust on the proceeds of the sale, and only awarded damages. See Grummel v. Hollenstein, 90 Ariz. 356, 367 P.2d 960 (1962) (refusing to reopen judgment to take evidence as to proceeds of sale to third party); Cushing v. Levi, 117 Cal. App. 94, 3 P.2d 958 (1931) (awarding as damages less than onethird of profit from sale to third party). A much higher price suggests that the second buyer had a higher valued use, and the failure of some courts to impose a constructive trust shows an unwillingness to prevent sellers from conveying to subsequent buyers who have more valuable uses. 
would realize from breaching. Although the promisee loses $\$ 3,000$ from breach, the promisor saves $\$ 7,000$. The negotiations over division of the net $\$ 4,000$ savings that breach makes possible are a deadweight efficiency loss. If only the damage remedy were available to the promisee, however, the promisee could still force such negotiations because he would retain the power to impose a $\$ 7,000$ loss on the promisor.

The standard damage measure for breach of a construction contract is the difference between the contract price and the new market price. ${ }^{55}$ In the hypothetical, the new market price would be $\$ 17,000(\$ 15,000$ cost plus the contractor's $\$ 2,000$ profit), and the contract price is $\$ 10,000$. Thus specific performance and the damages remedy create identical incentives for the parties to engage in costly post-breach negotiations in the event of unexpected inflation. ${ }^{56}$

\section{Efficiency Gains from the Routine Availability of Specific Performance}

The analysis thus far suggests that making specific performance widely available at the election of the promisee would not result in more costly pre- or post-breach negotiations than the damage remedy does at present. Further expanding the availability of specific performance would produce certain efficiency gains: it would minimize the inefficiencies of undercompensation, reduce the need for liquidated damage clauses, minimize strategic behavior, and save the costs of litigating complex damage issues.

First, if only a damage remedy is available, promisors may sometimes breach when their gains from breach exceed the damages a court will assess, though not the full costs breach imposes on the promisees. Such breaches may be inefficient for they make promisors better off but promisees worse off.

Second, under current law, parties have an incentive to create a "contractual" specific performance remedy in cases in which specific

\section{See Restatement $\$ 346$.}

56. The widget hypothetical used in text illustrates that expanding the availability of specific performance could sometimes result in overcompensation. Suppose that $S$ actually conveyed the widget to $B 2$, a good faith purchaser for value. B1 could not recover the widget from B2, nor could B1 get specific performance. In many jurisdictions he could, however, impose a constructive trust on the sales proceeds; thus he would recover $\$ 30$ rather than the contract market differential of $\$ 15$. The constructive trust remedy that a right to specific performance enables the promisee to invoke thus can overcompensate. The deterrent effect of the constructive trust, however, often is the only effective way of ensuring that a promisor will not defeat the promisee's right to specific performance by promptly conveying to a third party. The occasional overcompensation that results seems a reasonable price to pay in order to maintain the effectiveness of the specific performance remedy. 
performance is now prohibited or its availability is uncertain by negotiating liquidated damage clauses. ${ }^{57}$ This is because these clauses perform the same function as specific performance-ensuring adequate compensation or performance when damage rules provide neither. If specific performance were routinely available, much of the costs to the parties of negotiating liquidated damage clauses would be saved..$^{58}$

Third, commentators have argued that liquidated damage clauses that require relatively high payouts would create incentives for the promisee to breach when changed circumstances cause the promisee to prefer the payout to performance. ${ }^{59}$ Resources spent on inducing breach or on countering this conduct constitute deadweight efficiency losses. If specific performance were made widely available, however, contracting parties would have an incentive to choose it rather than liquidated damage clauses because, as we have seen, specific performance and liquidated damages often are substitutes. Since the gains to the promisee from inducing breach are greatly minimized when large damage payouts do not accompany it, such strategic behavior would rarely occur.

Finally, specific performance often is sought when damages would be difficult to establish. Granting the remedy in such cases would save the resources that would otherwise be devoted to exploring complex damage questions. ${ }^{60}$

\section{Administrative Cost Objections to Specific Performance}

The previous discussion has shown that certain efficiency gains can be expected as the result of expanding the availability of specific performance. One final efficiency objection remains-that the remedy increases the administrative costs of the parties and the courts because

57. See Goetz \& Scott, supra note 2, at 559.

58. There would be new costs associated with parties' "contracting out" of a general specific performance rule, which would in part offset these savings. As pp. 281-84 supra showed, however, the general preferences of the parties respecting specific performance or damages seem impossible to ascertain; thus any demonstrated savings from expanding the availability of specific performance should be considered a net gain.

59. See Clarkson, Miller, \& Muris, supra note 28, at 368-72. Liquidated damage clauses are not likely to inspire many attempts to induce breach, however, for if the penalty is high, the promisee would have to go to great lengths to get the promisor not to perform. Because any attempt to induce breach violates the promisee's duty to act in good faith and because the requisite extraordinary efforts should be relatively easy to prove, the promisee would probably be precluded from enforcing the liquidated damage clause if he engaged in such "strategic behavior." While Clarkson, Miller, and Muris recognize the relevance of the promisee's duty of good faith to their argument, they underestimate its force. $I d$. at 371 . For another criticism of their argument see A. Kronman \& R. Posner, The Economics of Contract 224-25 (1979).

60. See D. Dobbs, Remedies 885 (1973). 
of the expense entailed in creating and implementing specific performance decrees. This objection is at present the basis for a defense to a specific performance action: a court can deny the remedy on the ground of "difficulty of supervision" ${ }^{61}$ even if a plaintiff otherwise establishes a right to specific performance. An analysis of the administrative cost objection, however, establishes that the difficulty of supervision defense should be available much less frequently than current law permits. Two arguments support this view. First, as demonstrated below, it is often difficult to know whether the costs to courts of allowing a specific performance remedy would exceed the gains resulting from increased availability of the remedy. In situations in which a cost comparison between specific performance and damages is not possible, the more accurate remedy, specific performance, should be granted. Second, the administrative costs that the specific performance remedy imposes on the parties should not count against its wider use, because those costs will be incurred only when the parties perceive them to be lower than the gains from equitable relief.

Courts, in enforcing the supervision defense, are concerned with their inability to supervise performance ${ }^{62}$ and with the burden of further litigation..$^{63}$ Yet, as the cases of the civil rights and antitrust injunctions demonstrate, courts have effectively supervised contentious parties in complex matters over long periods. ${ }^{64}$ Courts that refuse to award specific performance on the basis of supervision difficulties seem implicitly to assume, however, that the costs of granting equitable relief exceed any benefits from doing so.

Granting specific performance does impose costs on courts. Judges may have to devote greater time and resources to tailoring and supervising a specific performance decree than would have to be devoted to devising and enforcing a damage judgment. Thus equitable relief can be given at the expense of judicial attention to other matters. ${ }^{65}$ Courts, however, can eliminate much of this opportunity cost by

61. See note 11 supra (citing cases in which the difficulty of supervision defense was allowed).

62. See, e.g., Thayer Plymouth Center, Inc. v. Chrysler Motors Corp., 255 Cal. App. 2d 300, 304, 63 Cal. Rptr. 148, 150 (1967) (specific performance denied for contract requiring continuing supervision); Egbert v. Way, 15 Wash. App. 76, 80, 546 P.2d 1246, 1248-49 (1976) (specific performance might properly be denied if judicial supervision were unreasonably difficult).

63. See, e.g., Yonan v. Oak Park Fed. Sav. \& Loan Ass'n, 27 Ill. App. 3d 967, 974, 326 N.E.2d 773, 779 (1975) (specific performance denied for construction contract where there was risk of further litigation).

64. Extensive illustrations are given in O. Fiss, InJuctions 325-481 (1972). See also O. Fiss, The Civil Rights Injunction 36-37 (1978).

65. This conclusion seems plausible intuitively, but may be incorrect because it assumes that the supply of judicial services is inelastic. In a recent statistical study, Professor 
appointing special masters. ${ }^{68}$ This practice would also shift any additional resource costs of specific performance primarily to the parties. Masters can be used to fashion decrees, as well as to supervise performance and hear appeals respecting compliance.

As the previous section has shown, increasing the availability of specific performance actually creates substantial efficiency gains. On the basis of information currently available, it is impossible to say whether those gains would exceed the increase in administrative and judicial opportunity costs that the availability of specific performance would engender. This is particularly so if courts delegated supervisory and other administrative tasks to masters. Because the normative goal of contract remedies is compensation, specific performance should lie unless it can be shown that the costs of specific performance would exceed the gains. As such a case has not been made, the administrative cost objection should seldom support denial of specific performance. ${ }^{67}$

The possibility that the parties will incur greater costs as a result of the specific performance remedy if supervision of a decree is required should not count against the wider availability of the remedy. These costs will be incurred only when the benefits of specific performance

Gillespie cast doubt on the validity of this assumption. See Gillespie, The Production of Court Services, 5 J. Legal Srud. 243 (1976). He found that federal district courts disposed of more cases when they conducted a higher proportion of trials. He suggested two explanations for these results. First, when courts use trials as a matter of course, the parties have greater incentives to settle. Second, the evidence suggests that the supply of judicial services is fairly elastic; as he put it, "judges work harder, longer or more efficiently when there is a need to do so." Id. at 264 .

This argument, as applied to specific performance questions, suggests that if courts issued a higher proportion of decrees that required supervision, they might not be forced to neglect other tasks, because the prospect of these decrees might induce more parties to settle or perform and because judges might expand output. Thus the opportunity cost of increased supervision might in fact be slight.

66. Masters have been used to help enforce specific performance decrees since Elizabethan times. See 1 G. Spence, Equirable Jurisdiction 647 (1846). Judge Hough was an influential advocate of the use of masters in this country. See Kearns-Gorsuch Bottle Co. v. Hartford-Fairmont Co., 1 F.2d 318, 319-20 (S.D.N.Y. 1921) (urging use of "competent receivers" to aid judges in supervising difficult business problems). Rule 53(b), however, states that use of a master "shall be the exception and not the rule." FED. $R$. Civ. P. 53(b). Commentators have argued that use of a master is an abdication of judicial functions, and that it increases the cost of litigation. See Note, Masters and Magistrates in the Federal Courts, 88 HARv. L. Rev. 779, 790-91, 791 n.82 (1975); Kaufman, Masters in the Federal Courts: Rule 53, 58 Colum. L. Rev. 452, 452-53 (1958). Neither objection is forceful in this context, however. Since a master's role would primarily be to supervise court decrees, courts would perform the major aspect of the judicial function. Furthermore, the costs of supervision do not vanish if a court performs them; they are simply externalized to the public fisc. The parties would more appropriately bear these costs because they are best able to minimize them. See pp. 295-96 infra.

67. See pp. 304-05 infra (discussing narrow circumstances in which difficulty of supervision defense should be permitted). 
exceed its incremental costs. ${ }^{68}$ The question remains, however, which party should absorb supervision costs if a court appoints a master. If both parties can calculate the expected value of these costs when they contract, this question is trivial. Suppose a rule is adopted that promisees must pay the costs of a master and other court costs associated with specific performance. In the Figure, let $\mathrm{D}$ be the demand curve for

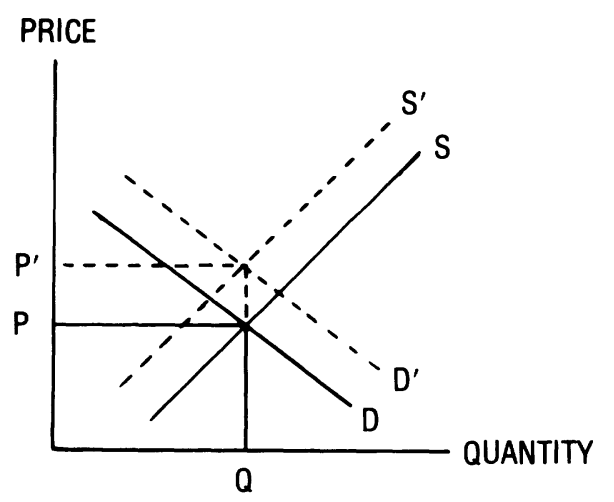

construction services, for example, and let $S$ be the supply curve. At equilibrium, quantity $Q$ of services are supplied at price $P$. If the rule were changed, and promisors were required to absorb the additional costs of specific performance, the supply curve would shift to $S^{\prime}$ because it would then be more expensive to supply construction services. The magnitude of the shift would reflect the expected value of these costs. The demand curve, however, would shift by roughly the same amount as the supply curve because construction services become more desirable to promisees: if a promisor breaches, a master's services are provided "free." ${ }^{69}$ Whereas the market price for construction services will rise to $\mathrm{P}^{\prime}$ when promisors bear the extra costs of specific performance, the quantity of services traded remains at $Q$. Therefore, no efficiency consequences result from allocating these costs to one party or the other.

This analysis assumes, however, that no information asymmetries exist. In fact, promisors may know more about the likelihood of their

68. This argument assumes certain knowledge on the part of the parties concerning the benefits and costs of equitable relief. See pp. 276-77 supra.

69. Because the costs of a master's services would be included in the contract price, the marginal cost to a promisee of using these services in the event of breach falls to zero. This could create a "moral hazard" problem because more masters' services will be consumed than if promisees had to pay for these services as they were required. The other costs of litigation that promisees would have to bear, however, seem high enough to make this problem unimportant. 
own breach than do promisees. If promisees were to bear the costs of masters, they might over- or underestimate them. Either mistake reduces allocative efficiency. In the former case, too few services are purchased; in the latter case, too many. At the same time, promisees know better than promisors whether and to what extent damages might be undercompensatory. Thus if promisors are made to bear the additional costs of specific performance, they may over- or underestimate these costs. Again, allocative inefficiency is likely to result. It is difficult to predict the direction in which these information asymmetries are most pronounced.

However, in the most important practical context, that of construction contracts, it is possible to predict the direction in which the asymmetries would be most pronounced. Construction promisors seem better able to predict the likelihood that damages will be unsatisfactory to promisees than promisees are able to predict the likelihood of breach. A promisee would have difficulty in predicting breach because there are probably numerous contractor promisors, and construction firms differ widely in competence and reliability. Thus the promisee would have to obtain data about numerous firms; the promisee could not instead rely on common knowledge about the reliability of the service. In addition, consumer promisees would have even greater difficulty in predicting breach. Consumers use major construction services infrequently, and thus lack the incentive to explore market conditions in detail as well as the opportunity to obtain expertise in evaluating market data. On the other hand, construction firms in all markets often can assess the relative "uniqueness" of their own performances. Therefore, greater misallocations would probably result if promisees rather than promisors bore the costs of supervision. Thus breaching promisors should bear these costs in construction contexts. ${ }^{70}$

\section{Specific Performance and Liberty}

The analysis thus far indicates that none of the efficiency arguments against expansion of the availability of specific performance are persuasive, except in the rare cases in which the difficulty of supervision defense properly applies. There is, however, another basis for objection to specific performance. A moral objection to expansion of the availability of this remedy can be raised on the ground that requiring per-

70. To allow for exceptional individual circumstances, parties should be permitted to contract out of this rule. 
formance interferes with the promisor's liberty more than requiring the payment of money. If this liberty interest takes precedence over the goals that specific performance serves, the equitable remedy should be prohibited or restricted. ${ }^{71}$ The liberty interest objection consequently cannot be evaluated fully without a theory that would either reconcile or enable choice to be made among four arguably relevant goals of contract law: (i) to permit a promisor freely to choose the terms under which to contract, including an implied term providing for specific performance; (ii) to prevent a promisor from the possibly undue compulsion of having to perform; (iii) to minimize the costs of undercompensation; (iv) to give the promisee the performance he bought because he is morally entitled to it. Developing such a metatheory is beyond the scope of this Article, but fortunately it is not necessary to deal with most of the liberty interest arguments.

To begin, a promisor's liberty interest is not seriously compromised by a specific performance decree if the promisor sells roughly fungible goods or is in the business of selling unique goods. In either circumstance, the goods are assets to the promisor much like cash; requiring their delivery is not relevantly different from requiring the delivery of cash. Similarly, requiring a sizable corporation that renders services to perform for a given promisee does not violate the corporation's associational interests or the associational interests of its employees.

Liberty interests are affected, however, in the case of an individual promisor who performs personal services. In part for this reason, current law does not allow specific performance to be granted in this case. ${ }^{72}$ Liberty interests might also be implicated if a promisor were required to deliver goods or realty to which he has a sentimental attachment, on the ground that his liberty comprehends the right to define himself partly in terms of the possession of tangible things. ${ }^{73}$ The law, however, commonly awards specific performance in such cases; goods which have sentimental associations for the promisor may

71. The distinction in French law between "obligations to do and not to do" and "obligations to convey" reflects this concern. Breach of the former is compensable only in damages, whereas breach of the latter may be remedied by an order equivalent to specific performance. Different remedies apply because " $[\mathrm{i}] \mathrm{t}$ was considered less onerous to owe money than to be liable to compulsion actually to perform an act or forebearance." Treitel, supra note 24, at 13.

72. See Lumley v. Wagner, 42 Eng. Rep. 687 (1852) (personal services contract enforced by enjoining performance elsewhere rather than by requiring specific performance); RESTATEMENT $\$ 379$ (same).

73. This "personality theory of property" is usually traced to Hegel. See G. HegeL, Philosophy of Right \$ 41-71 (T. Knox trans. 1972); S. Avineri, Hegel's Theory of the MODERN State 88-89, 135-37 (1972). 
not have close substitutes for the promisee, ${ }^{74}$ while all realty is presumed unique. ${ }^{75}$

The liberty interest objection thus poses no barrier to expanding the availability of specific performance to sales of roughly fungible goods and corporate services. But it does suggest eliminating use of the remedy in some cases in which it now is available. This suggestion is premature, however. To limit specific performance with regard, say, to unique goods would first require the development of a coherent theory of the "personality aspect" of property ownership. It must then be shown that protection of the liberty interest to which the theory gives rise is more important than the goals that specific performance is thought to serve. Until this showing is made, liberty motivated exceptions to a rule of specific performance on promisee request should not be created.

\section{Defenses to Specific Performance}

Under current law, a promisee cannot obtain specific performance simply by showing breach and the absence of an adequate remedy at law; special defenses that apply only to requests for specific performance further limit the availability of the remedy. These defenses include inadequacy of consideration, lack of security for the promisee's performance, unilateral mistake by the promisor, and difficulty of supervising performance. ${ }^{76}$ They can be divided into two categories, those stemming from perceived unfairness of the contract and those stemming from perceived difficulties in implementing the remedy.

\section{A. Unfair Contracts}

When a promisee cannot prove damages, denial of an equitable remedy constitutes a decision not to enforce the contract. ${ }^{77}$ Because

74. For example, “[h]eirlooms, family treasures . . ., a grandfather's clock . . . a baby's worn-out shoe, or faithful old Dobbin the faithful horse . . ., REstatement $\S 361$ Comment e, are goods with "sentimental associations" that may justify a grant of specific performance. $I d$. $\S 361(\mathrm{~b})$. Such items may have sentimental associations for promisors as well as promisees.

75. For a striking example of a grant of specific performance in spite of the promisor's sentimental attachment to the property, see Hutchins v. Honeycutt, 286 N.C. 314, 210 S.E.2d 254 (1974) (conveyance of "The old Home Place").

76. See p. 273 and notes 8-11 supra.

77. This conclusion is intuitively valid and some data exists to support it. In a survey covering 150 cases in which specific performance was denied on grounds of equitable unfairness, the 56 responses showed that "[i]n every instance, an equitable defeat was a total defeat." Frank \& Endicott, Defenses in Equity and "Legal Rights," 14 LA. L. REv. 380, 381 (1954). 
defenses to specific performance differ from defenses at law, there are in effect two doctrines regulating relief from contractual obligations, "equitable" and "legal" unconscionability. Two features distinguish the equitable version. First, courts often refuse to enforce contracts in equity-that is, deny specific performance-on the ground that particular clauses are substantively unfair, without reaching the issue of whether the contracting process itself was also unfair. Second, when equity courts do require process unfairness as a condition of nonenforcement, their version of it seems different from and easier to establish than the process unfairness required in actions at law. These two features are unjustifiable and produce confusion and unpredictability. They should thus be abolished, so that the defenses that can be asserted against a request for specific performance will be identical to those that can be asserted against a request for damages.

\section{A Too Low Price}

A promisor can defeat an action for specific performance in some jurisdictions by proving that the contract price is too low. ${ }^{78}$ Though this defense is meant to rescue promisors from bad deals, it does the job poorly. Suppose a party contracts to sell for $\$ 5,000$ property that, judging from sales of similar property, has a market value of $\$ 10,000$. Both specific performance and damages would impose a $\$ 5,000$ loss on the promisor in the event of breach. Now suppose instead that property similar to the subject of sale is not commonly traded in the promisor's area, but experts attest that the property at issue is "worth" much more than $\$ 5,000$. In this latter case, the breaching promisor would prefer the promisee to be limited to a damage action. The difficulty of measuring damages might cause a court to order the promisor only to make restitution or to award a sum as damages that is less than the value of the property to the promisor. Thus contracts with allegedly inadequate prices are enforced when damages are provable but not when damages are not provable.

There is no normative justification for making promisor protection turn on the promisee's ability to establish damages rather than on the price that the parties set. This difficulty can be avoided by making the defense of a too low price generally available in contract law, or by

78. See note 8 supra (citing cases in which specific performance was denied due to inadequacy of consideration). Courts may grant specific performance, however, despite an apparent inadequacy of consideration. See, e.g., Gross v. J \& L Camping \& Sports Center, Inc., 270 Md. 539, 312 A.2d 270 (1973) (price was $\$ 85,000$, value apparently above $\$ 120,000)$; Blankenship v. Porter, 479 S.W.2d 409 (Mo. 1972) (price was $\$ 6,000$, value said to be $\$ 12,000$ ). 
abolishing it. There are two principal reasons why the defense should be eliminated entirely. First, the defense leads to unpredictable outcomes. Unpredictability arises because the defense is often asserted in cases involving goods for which no recognized markets exist. In consequence, courts are often required to resolve the difficult issue of what the property is "worth," as well as the more difficult issue of what fraction of this worth justice requires the seller to receive. Because judicial outcomes on these issues are difficult for the parties to predict, promisors frequently assert the defense and thus force courts to spend time considering it. ${ }^{79}$ Resources would be saved if the defense were eliminated.

Moreover, contracts involving low prices should be enforced because enforcing such contracts creates incentives for promisees to seek out good deals. Increased search, in turn, correlates positively with the existence of competitive prices, for the more comparison shoppers there are, the more likely it is that sellers can increase profits by offering lower prices. ${ }^{80}$ Since competitive prices are preferable to supracompetitive prices, the defense that a too low price alone ought to bar specific performance should be eliminated.

Some courts allow the defense of inadequate consideration only if there was also unfairness in the contracting process. ${ }^{81}$ Because some forms of process unfairness, such as misrepresentation, are inconsistent with competitive outcomes, this version of the defense seems justifiable. But the forms of process unfairness that support a denial of specific performance should be the same as those that support a finding of unconscionability at law. Otherwise, promisor protection does turn on the promisee's ability to prove damages rather than on the unfairness that actually occurred; if "equitable" unconscionability is easier for a promisor to establish than legal unconscionability, the promisee will sue at law if possible. Furthermore, since the factors that make up legal unconscionability are themselves suspect, ${ }^{82}$ the vaguer equitable ver-

79. See, e.g., Loeb v. Wilson, 253 Cal. App. 2d 383, 388, 61 Cal. Rptr. 377, 380 (1967) (two expert real estate appraisers testified as to adequacy of consideration). In at least one jurisdiction, a motion for specific performance must allege the value of the property in order to allow the court to judge the adequacy of the consideration. See, e.g., Georgia Money Corp. v. Monteleone Apartments, Inc., 223 Ga. 418, 418-19, 156 S.E.2d 39, 39-40 (1967).

80. See Schwartz \& Wilde, supra note 35 , at $640-51$.

81. See, e.g., In re Estate of Brown, 130 Ill. App. 2d 514, 264 N.E.2d 287 (1970); Peters v. Wallach, 366 Mass. 622, 321 N.E.2d 806 (1975).

82. See Epstein, Unconscionability: A Critical Reappraisal, 18 J. L. \& Econ. 293 (1975); Schwartz, A Reexamination of Nonsubstantive Unconscionability, 63 VA. L. REv. 1053 $(197 \rightarrow$ Trebilcock, The Doctrine of Inequality of Bargaining Power: Post-Benthamite Economics in the House of Lords, 26 U. TORONTO L.J. 359 (1976). 
sion is even less attractive ${ }^{83}$ Finally, having two versions of unconscionability, both of which are unpredictable in application, generates excessive uncertainty costs. Thus, the standards of legal unconscionability should furnish the guidelines for the process unfairness version of the too low price defense.

\section{Unfair Terms}

The unfair contract terms defense is best discussed in the context of an illustration. Consider the rule used in some jurisdictions that specific performance is denied if the promisee's performance is inadequately secured. ${ }^{84}$ This defense is often invoked in the case of installment contracts that fail to require the promisee to give a purchase money mortgage. ${ }^{85}$

Suppose a party contracts to sell property for $\$ 8,000$ and the market price has risen to $\$ 10,000$ at the time of performance. Under the contract, the price is to be paid in installments, but the promisee fails to give security. The promisor then breaches. Though it appears at first that the promisor would be indifferent between specific performance and damages, the promisor would, in fact, prefer to pay damages. Although the legal remedy deprives the promisor of the $\$ 2,000$ increment in value, it permits him to sell the property to another on a secured basis and thus be relatively assured of receiving the full price. If the promisor instead were specifically required to perform, he would be forced to sell to the original promisee on an unsecured basis. Indeed, denial of the remedy in these circumstances seems to be a pareto

83. See Hutchins v. Honeycutt, 286 N.C. 314, 210 S.E.2d 254 (1974); II J. Pomeroy, Equity Jurisprudence $\S 400$ (1941); Restatement (Second) $\S 378$, Comment a, Illustrations (1) and (4).

A good example of the vacuousness of equitable unconscionability is given in Morgan v. Reasor, 204 N.W.2d 98 (S.D. 1973), in which the court refused to require specific performance of a contract to exchange a ranch for an apartment complex. The sellers had purchased a 3,362 acre ranch for $\$ 169,500$, and reneged on an agreement to exchange it for an apartment complex. The buyer had claimed that the complex would operate at a profit, the chances of which were slight. The court explained:

$[T]$ he evidence discloses that this Pennington County rancher was without understanding of a transaction of this nature and magnitude. There is such a lack of competency on the part of the defendants as to have made it necessary that they should have had protection and advice; these facts coupled with the circumstances that the Reasors were misled as to the value of Whispering Sands, and that they, in effect, were actually giving their ranch away is sufficient in our opinion to constitute constructive fraud.

Id. at 109.

84. See note 9 supra (citing cases denying specific performance on grounds that promisee's performance was inadequately secured).

85. Id. 
superior move; ${ }^{86}$ the promisee is as well off with damages as with the property, while the promisor is better off if he is free to sell elsewhere on more favorable terms.

If damages are undercompensatory, however, as is commonly the case in suits for specific performance, promisors are made better off but promisees worse off by the defense. Some courts attempt to take this into account by granting specific performance if the promisee furnishes a mortgage or other adequate security ${ }^{87}$ This version of the unfair terms defense, however, does not produce a pareto superior outcome; instead, it inappropriately redistributes wealth from promisees to promisors and creates uncertainty. Suppose in the earlier example that the implicit price of a purchase money mortgage is $\$ 500 .{ }^{88}$ Then making the grant of specific performance conditional on the promisee's provision of a purchase money mortgage in effect raises the price of the house, which would have been $\$ 7,500$ in a secured sale. Yet courts do not reduce the price when requiring a mortgage as a precondition to specific performance. The resultant redistribution seems unjustified; the promisee in this illustration was not guilty of process unfairness in making the contract, yet the promisor receives a price increase because he balked at completing a deal to which he freely agreed. ${ }^{89}$ Furthermore, uncertainty is created because promisees would have difficulty predicting actual transaction prices in the event of breach since the parties seldom calculate implicit prices for terms such as mortgages at the time the price is negotiated.

These arguments can be generalized to cover any contract term challenged on fairness grounds. A court can either deny specific performance altogether ${ }^{90}$ or condition its grant on deletion of the offend-

86. For a definition of the concept of pareto superiority, see J. Hirshleifer, Price Theory AND APPlications 441 (1976). In brief, solution $A$ is pareto superior to solution $B$ if everyone is as well off under $A$ as under $B$, and at least one individual is better off under A. Id.

87. See, e.g., Rego v. Decker, 482 P.2d 834, 838 (Alaska 1971); Restatement § 373.

88. An "implicit price" is the price that would have been charged for a contract term or product feature if the parties had separately priced it. This example is more realistic than the previous example, see p. 301 supra, which inaccurately presupposed that mortgages did not have implicit prices.

89. The Restatement unpersuasively justifies making grant of specific performance conditional on the provision of security on the ground that " $t]$ here is no injustice to the plaintiff in requiring the reduction of that risk [of nonpayment], as the price of getting so drastic a remedy." Restatement $\$ 373$, Comment a. This argument ignores the fact that increased risk in a transaction results in a higher price. Thus a decrease in risk should result in a decrease in price.

90. See Campbell Soup Co. v. Wentz, 172 F.2d 80, 83 (3d Cir. 1948); Restatement (SECOND) $\$ 378(1)(c)$ (specific performance will be denied if contract itself is unfair). 
ing contract term.91 Both solutions are pareto superior to specific performance when damages are fully compensatory. When damages are not compensatory, the latter solution is preferable because the promisor would be as well off with a conditioned grant as with denial of the remedy, while the promisee in some cases would be better off. However, making grant of the remedy conditional is itself a questionable response to the problem of unfair terms because it redistributes wealth inappropriately and creates uncertainty.

The appropriate solution to the unfair terms problem in light of these difficulties is to permit the conditional grant version of the defense only if it is accompanied by unfairness in the contracting process. The existence of such unfairness largely vitiates the objections to the defense. First, any redistributions engendered by making the grant of specific performance conditional seem justifiable; the promisee has behaved inappropriately with the apparent result that the promisor was influenced to make a worse deal than he otherwise would have made. Second, while deals made on favorable terms should be enforced so as to induce promisees to search for good deals and thereby promote competitive outcomes, process unfairness often produces noncompetitive outcomes. Third, uncertainty will be reduced because a promisee not guilty of process unfairness knows that his deal will be enforced on the original terms. Also, the process unfairness necessary to trigger application of the unfair terms defense should be measured by legal rather than equitable standards. ${ }^{92}$

91. See, e.g., Rego v. Decker, 482 P.2d 834, 839 (Alaska 1971) (grant conditional even when promisor explicitly assumed risk of nonperformance by promisee); REstatement $\S 373$, Comment b (same).

92. None of these objections apply to the rule that specific performance will be denied if the promisee lacks "clean hands," that is, if he fails to perform in accordance with the terms of the contract. See Fultz v. Graven, 7 Ill. App. 3d 698, 699, 288 N.E.2d 491, 491-92 (1972); Shannon v. Gull Lake Ass'n, 11 Mich. App. 644, 645, 162 N.W.2d 111, 111 (1968). If a plaintiff fails so to perform, the contract itself bars his claim to the defendant's performance.

The defense of unilateral mistake, however, is subject to the criticisms made of the defense of unfair terms. Some courts deny specific performance if the promisor failed to understand the terms of the contract even though the promisee did not conceal those terms. See note 10 supra. If one party takes advantage of the supposed ignorance or lack of sophistication of the other party, the court may refuse to enforce the contract. See Uniform Consumer Credit Code $\$ 5.108(4)$ (e) (1974). Because this rule is itself open to attack on the ground that a person's freedom to contract is unduly restricted if it is too lightly presumed that he is incompetent, see Schwartz, supra note 82 , at 1076-82, equity courts should go no further. Some support for this argument is found in the fact that some courts grant specific performance when the unilateral mistake could have been prevented by the promisor's due diligence. See Tayyara v. Stetson, 521 P.2d 185, 189 (Colo. App. 1974); Van Curler Dev. Corp. v. City of Schenectady, 59 Misc. 2d 621, 628, 300 N.Y.S.2d 765, 775 (1969). 


\section{B. Difficulty of Supervision}

The difficulty of supervision defense largely rests on the assumption that specific performance unduly raises administrative costs. ${ }^{93}$ As indicated above, the administrative cost objection is much less forceful than is commonly supposed. This defense, however, also rests on a related premise-that courts should not do ineffectual tasks. ${ }^{94}$ When the promisor wants to avoid performing, even a specific performance decree may not cause him to render the promised performance satisfactorily. Given this possibility, three arguments can be made in support of the difficulty of supervision defense: (i) the decree would not be in the promisee's best interests; (ii) judicial prestige will suffer if court decrees are flouted; (iii) courts should not waste judicial resources. The first basis for the defense is untenable; it should be the promisee's choice whether to risk the possible defects of a coerced performance. Furthermore, the promisee is better able to assess the likelihood of compliance than a court because the promisee knows more about the promisor.

Although the second argument is based on a legitimate concern, it does not support denial of the remedy. Because the costs to a promisor of noncompliance with a court decree are likely to be high, and because business promisors seldom breach for ideological reasons, substantial compliance with most decrees can be expected. Further, the typical contract law dispute is unlikely to attract publicity; consequently, any noncompliance will not adversely affect the public perception of the courts. In the event, however, that noncompliance seems particularly likely in a given case, and the noncompliance is likely to be publicized, a court could justifiably deny specific performance under the difficulty of supervision defense.

The third argument also will rarely support denial of the remedy. Judicial resources will not be wasted because a promisee is unlikely to seek specific performance unless the gain-substantial compliance

93. For standard statements of the defense, see D. DoвBs, supra note 60, at 908-09; Restatement (SECOND) $\S 380$. Courts in some jurisdictions grant specific performance even though it involves extensive supervision. See, e.g., Laclede Gas Co. v. Amoco Oil Co., 522 F.2d 33, 39 (8th Cir. 1975); City Stores Co. v. Ammerman, 266 F. Supp. 766, 776-78 (D.D.C. 1967), aff'd, 394 F.2d 950, 956 (D.C. Cir. 1968); Pembroke Park Lakes, Inc. v. High Ridge Water Co., 213 So.2d 727, 728-29 (Fla. App. 1968).

94. The Restatement (Second) articulates this premise of the difficulty of supervision defense:

Difficult questions may be raised as to the quality of the performance rendered

under the decree. Supervision may be required for an extended period of time.

Specific relief will not be granted if these burdens are disproportionate to the ad-

vantages to be gained from enforcement and the harm to be suffered from its denial. Restatement (SECond) $\S 380$, Comment a. 
by the promisor-exceeds the associated costs. Moreover, as suggested previously, much of the cost of supervision can and should be allocated to the parties.

Thus arguments based on the premise that courts should refuse to assume ineffectual tasks only support a quite restricted use of the difficulty of supervision defense. There are cases in which the cost of a master would be enormous in relation to the stakes at issue, in which the court is aware that publicized noncompliance is likely, or in which the plaintiff is seeking specific performance out of spiteful motives. Although such cases are rare, courts should have the power to deny specific performance when necessary. Ordinarily, however, even if a court or master would have to engage in extensive supervisory tasks, a promisee should have the option of requesting the remedy of specific enforcement. ${ }^{95}$

\section{Conclusion}

The compensation goal of contract law can be achieved by requiring the promisor to pay damages or by requiring the promisor to render the promised performance. Under current law, a promisee is entitled to a damage award as of right but the court retains discretion to decide whether specific performance should be granted. Because specific performance is a superior method for achieving the compensation goal, promisees should be able to obtain specific performance on request. An expanded specific performance remedy would not generate greater transaction costs than the damage remedy involves, nor would its increased use interfere unduly with the liberty interests of promisors. Making specific performance freely available also would eliminate the uncertainty costs of planning and litigation created by the difficulty of predicting whether the remedy will be available. In addition, this reform would reduce the negotiation costs incurred by parties in at-

95. A defense related to the difficulty of supervision defense is uncertainty of terms. Specific performance is denied when a contract's terms are too uncertain, even though the uncertainty might not defeat a damage action. See, e.g., S. Jon Kreedman \& Co. v. Meyers Bros. Parking-Western Corp., 58 Cal. App. 3d 173, 180-81, 130 Cal. Rptr. 41, $46-47$ (1976); Restatement (Second) $\S 376$, Comment $b$. If the contract's meaning is unclear, a court would have difficulty in framing a specific performance decree, but would also have difficulty in making a damage award. Thus if a contract is not too uncertain to enforce at law, it should be enforceable in equity. See W. WALSH, supra note 22, at 329-30. A more stringent standard of certainty might be required in equity on the ground that a promisor may have a greater liberty interest in not being compelled to perform acts than in not being forced to pay money. See pp. 296-97 supra. This justification is unsatisfactory, however, because the liberty interest distinction between conveying property or performing services and paying money is obscure. 
tempting to create forms of contractual specific performance such as liquidated damage clauses. ${ }^{96}$ Further, defenses to requests for specific performance that rest on unfairness of contract terms or prices and that differ from the defenses in actions at law should be eliminated; the grounds for denial of specific performance should be the same as those that now will bar a damage suit. Finally, the defense based on difficulty of supervision should be greatly restricted. If the law is committed to putting disappointed promisees in as good a position as they would have been had their promisors performed, specific performance should be available as a matter o̊ course to those promisees who request it.

96. This conclusion is similar to the conclusion Professor Fiss reached with regard to injunctions:

I will urge that the traditional view give way to a nonhierarchical conception of remedies, where there is no presumptive remedy, but rather a context-specific evaluation of the advantages and disadvantages of each form of relief. It should not be necessary to establish the inadequacy of alternative remedies before the injunction becomes available; at the same time, the superiority of the injunction should not be presumed, but rather dependent on an analysis of its technical advantages and the system of power allocation that it implies.

My plea is not confined to the civil rights injunction, but should extend to all types of injunctions.

O. Fiss, The Civil Rights Injunction 6 (1978). Contract remedies also should be "nonhierarchical," so that promisees need not "establish the inadequacy of alternative remedies before" specific performance is available. Id. This Article's argument goes further toward authorizing equitable relief than does Professor Fiss's analysis, both because of the clear superiority of specific performance over damages in achieving the compensation goal and because "a context-specific evaluation of the advantages and disadvantages of each form of relief," id., shows that this superiority can usually be purchased at relatively slight, if any, net cost. 